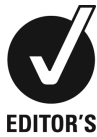

CHOICE

\title{
Langerhans cell histiocytosis (LCH) of the mandible in an adult: a rare case
}

\author{
Naga Himabindu Vennamaneni, ${ }^{1}$ Sumit Majumdar, ${ }^{1}$ Nalam Sai Gautam, ${ }^{2}$ \\ Divya Uppala ${ }^{1}$
}

${ }^{1}$ Department of Oral Pathology, GITAM Dental College and Hospital, Visakhapatnam, Andhra Pradesh, India ${ }^{2}$ Department of Pedodontics, GITAM Dental College, Vishakhapatnam, Andhra Pradesh, India

\section{Correspondence to}

Dr Nalam Sai Gautam, gautham316@rediffmail.com

Accepted 17 December 2014

\section{DESCRIPTION}

Langerhans cell histiocytosis (LCH) is a clonal proliferation of Langerhans cells (immature dendritic cells) occurring as an isolated lesion or as part of a systemic (multifocal) proliferation. LCH is classified under dendritic cell-related disorders. It can affect bone, skin, lymph nodes, thymus, bone marrow, viscera (spleen and liver), nervous system and the gastrointestinal tract. ${ }^{1}$ It has been diagnosed in all age groups, but is predominantly seen in children. In adults the incidence is $1-2$ cases per million. ${ }^{2}$

A 29-year-old male patient presented with a history of painless swelling in the lower jaw since 2 months. On palpation a single palpable, nontender, freely movable right submandibular lymph node was evident.

Intraoral examination was not remarkable. Mandibular occlusal radiograph revealed buccal cortical expansion (figure 1). Orthopantamogram

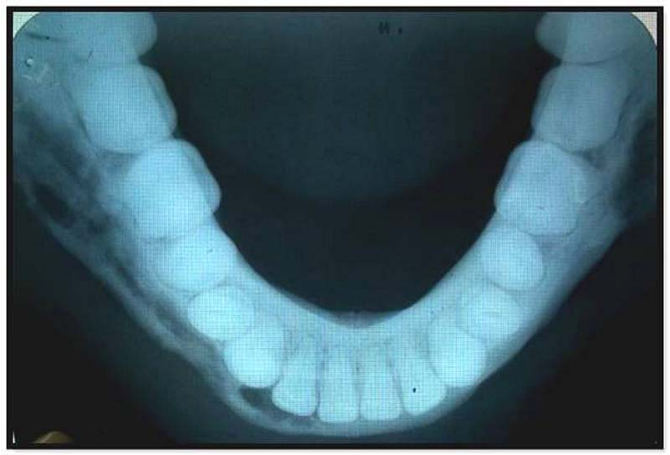

Figure 1 Occlusal radiograph shows buccal cortical expansion.

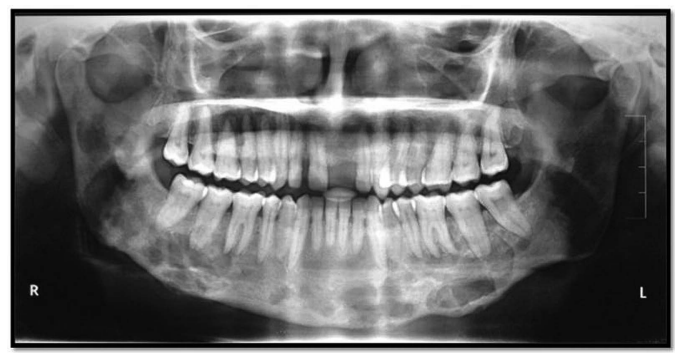

Figure 2 Orthopantamogram shows multiple ill-defined radiolucencies. revealed multiple, ill-defined radiolucencies in the mandible (figure 2).

Haematological investigations showed a significant increase in eosinophil count-17\%. Microscopic examination $(\mathrm{H} \& \mathrm{E})$, revealed cellular proliferation in the form of sheets, with cells characterised by unique reniform nuclei with pale eosinophilic cytoplasm representing Langerhans cells (figure 3), interspersed with numerous acute and chronic inflammatory infiltrate. Immunohistochemical evaluation of CD1a (figure 4), S-100 were positive. Entire body imaging was performed, which revealed no evidence of lesion in other organs. Based on these findings we came to a diagnosis of $\mathrm{LCH}$ affecting the mandible.

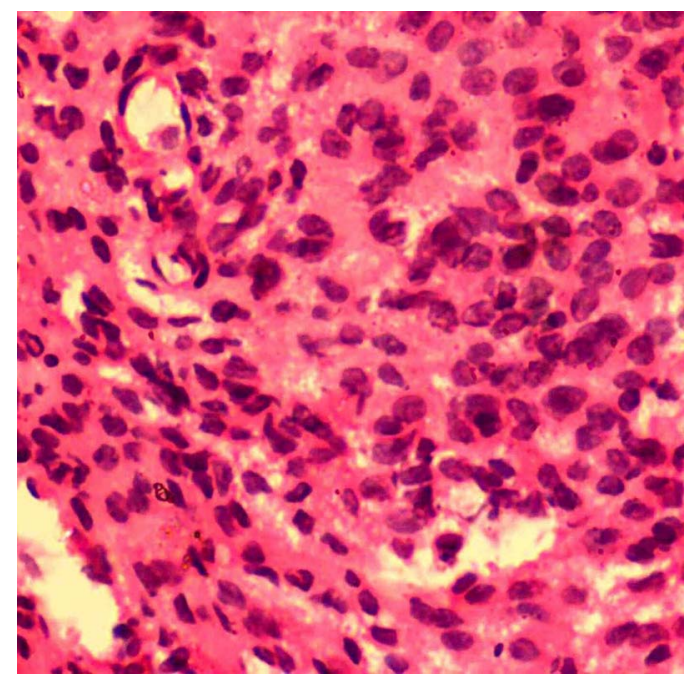

Figure 3 Proliferation of neoplastic Langerhans cells ( $\times 40$ view, $H \& E$ ).

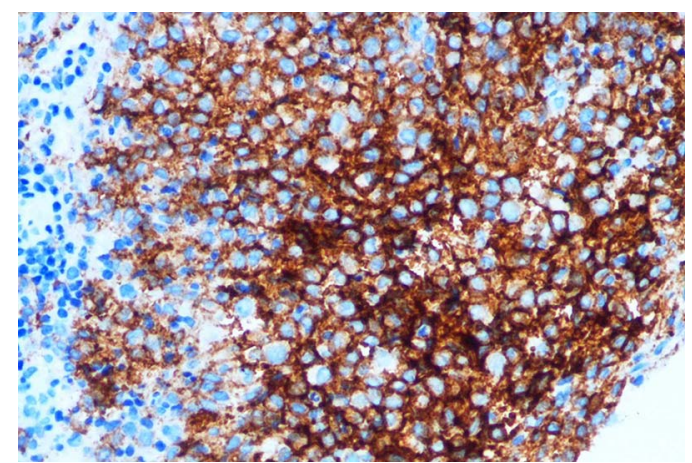

Figure 4 CD1a was positive $(\times 20$ view, immunohistochemistry). 


\section{Learning points}

- Although a rare lesion in an adult, Langerhans cell histiocytosis (LCH) should be considered as a differential diagnosis among the multilocular radiolucencies of the jaw.

- A meticulous clinicopathological correlation with immunohistochemistry as an adjunct is the gold standard for diagnosis of $\mathrm{LCH}$.
Competing interests None.

Patient consent Obtained.

Provenance and peer review Not commissioned; externally peer reviewed.

\section{REFERENCES}

1 Hicks J, Flaitz CM. Langerhans cell histiocytosis: current insights in a molecular age with emphasis on clinical oral and maxillofacial pathology practice. Oral Surg Oral Med Oral Pathol Oral Radiol Endod 2005;100:542-66.

2 Berber I, Erkurt MA, Kuku I, et al. A rare disease in adult: Langerhans cell histiocytosis. World J Oncol 2013;4:165-8.

Copyright 2015 BMJ Publishing Group. All rights reserved. For permission to reuse any of this content visit http://group.bmi.com/group/rights-licensing/permissions.

BMJ Case Report Fellows may re-use this article for personal use and teaching without any further permission.

Become a Fellow of BMJ Case Reports today and you can:

- Submit as many cases as you like

- Enjoy fast sympathetic peer review and rapid publication of accepted articles

- Access all the published articles

- Re-use any of the published material for personal use and teaching without further permission

For information on Institutional Fellowships contact consortiasales@bmjgroup.com

Visit casereports.bmj.com for more articles like this and to become a Fellow 